\title{
Modelowanie położenia jednostek kompleksów rolniczej przydatności gleb na podstawie przetwarzania ograniczonych informacji fizjograficznych i glebowych ze zdigitalizowanych materialów kartograficznych
}

\begin{abstract}
Streszczenie: Celem badań było przetestowanie możliwości modelowania zróżnicowania jednostek kompleksów rolniczej przydatności gleb na podstawie ograniczonych informacji o uziarnieniu oraz danych o morfologii terenu. Dane pozyskano z digitalizacji map glebowo-rolniczych oraz topograficznych z rejonu Górnośląskiego Okręgu Przemysłowego. Narzędziami ekstrakcji reguł i budowy modeli były algorytmy z zakresu inteligencji obliczeniowej: różne wersje drzew decyzyjnych, sieci neuronowe oraz algorytmy głębokiego uczenia. Najlepsze algorytmy pozwalały na poprawne zaklasyfikowanie do $90 \%$ elementów zbioru walidacyjnego. Konstrukcja zespołu klasyfikatorów z wyspecjalizowanym algorytmem decyzyjnym podwyższyła skuteczność identyfikacji zbioru walidacyjnego do około 94\%. Odpowiedni dobór algorytmu decyzyjnego pozwala na oszacowanie wektora prawdopodobieństwa przynależności obiektu do kompleksu. Algorytmy inteligencji obliczeniowej, można rozważać jako narzędzia ekstrakcji reguł klasyfikacji ze zbiorów danych o glebach, w ujęciu lokalnym lub regionalnym.
\end{abstract}

Słowa kluczowe: Mapa glebowo-rolnicza, kompleks przydatności rolniczej, digitalizacja, inteligencja obliczeniowa, modele adaptacyjne

\section{WSTĘP}

Analogowa dokumentacja kartograficzno-glebowa przedstawia dyskretny obraz zmienności przestrzennej przydatności gleb do pełnienia różnorodnych funkcji, głównie produkcji biomasy. Zazwyczaj, obok jednostek systematycznych i klasyfikacyjnych, kontury glebowe zawierają opis charakteryzujący rozkład uziarnienia w profilu glebowym lub pochodzenie geologiczne tworzywa mineralnego gleb. Informacje te maja charakter statyczny i dyskretny (Strzemski et al. 1964, Strzemski et al. 1973).

$\mathrm{Z}$ upowszechnieniem się technologii informacyjnych widoczna jest tendencja do transformowania tradycyjnych materiałów kartograficznych do postaci odpowiednio spreparowanych baz danych cyfrowych (Białousz et al. 2010). Naturalnym kandydatem do przeprowadzenia tej operacji są systemy GIS/LIS, składające się $\mathrm{z}$ baz danych oraz zbioru reguł określających relacje między nimi. Użyteczność GIS/LIS w procesie wizualizacji zjawisk przestrzennych wynika głównie $\mathrm{z}$ łatwości $\mathrm{w}$ formułowaniu zadań $\mathrm{z}$ zakresu algebry map, wyszukiwania obiektów spełniających określone warunki oraz wyłączania treści zbędnych, zaciemniających poszukiwaną informację. Cy- frowa forma danych pozwala także na analizy niedostępne w innych okolicznościach, na przykład znajdowania relacji między jednostkami ujętymi w bazie danych.

Jednym z problemów kartografii gleb jest uwzględnienie przestrzennej zmienności cech oraz zasięgu jednostek glebowych. Algorytmy przetwarzania danych cyfrowych, szczególnie przy dużej liczbie informacji, pozwalają na wyszukiwanie reguł, prawidłowości i wyjątków w obszernych bazach danych. Umownym terminem określającym przetwarzanie bardzo obszernych zbiorów danych jest pojęcie BigData, często łączony z pojęciem tak zwanego głębokiego uczenia (Deep Learning), czyli wykorzystania stosunkowo dużych architektur modeli, mających na celu wyodrębnianie reguł i wyjątków charakteryzujących dane. Pojęcie BigData jest związane z systemami generującymi z natury rzeczy obszerne zbiory danych (sieci sprzedaży detalicznej, obsługa rezerwacji, systemy bankowe itp.), lecz mogą to być też dane wygenerowane $w$ celu opracowania użytecznych modeli rzeczywistości. Pierwszym etapem takiej analizy jest akwizycja danych, czyli zgromadzenie ich w formie umożliwiającej ich efektywne przetwarzanie. 
W przypadku wyszukiwania reguł użytecznych w modelowaniu zasięgu jednostek glebowych zachodzi potrzeba włączenia do baz danych systemów informacji przestrzennej dodatkowych danych morfologicznych (rzędne terenu, spadki lokalne, konfiguracja otoczenia, położenie wody gruntowej itp.). Następuje w ten sposób powiązanie dyskretnych w przestrzeni jednostek systematycznych i klasyfikacyjnych gleb z ciagłymi cechami fizjograficznymi. Znanymi realizacjami takich koncepcji są modele SoLIM (Zhu et al. 2001) oraz SCORPAN (McBratney et al. 2003). Modele te odchodzą od tradycyjnego, dyskretnego obrazu zróżnicowania gleb, posługując się generalnie stopniem podobieństwa określonej konfiguracji zmiennych opisujących gleby do wzorców, niezdefiniowanych a priori, lecz zbudowanych na podstawie analizy rzeczywistych danych. Kluczowymi składnikami tych modeli są reguły wiążące fizjografię terenu z rozmieszczeniem jednostek klasyfikacyjnych. Reguły tych powiązań mogą być rozpatrywane w ramach problemu klasyfikacyjnego. Bardzo zaawansowane sa projekty realizacji bazy danych gleb Unii Europejskiej (Jones et al. 2005). Koncepcje odmiennego podejścia do kartografii cyfrowej prezentowane są także w Polsce np. Bielska i Jaroszewicz (2012), Białousz et al. (2010).

Problem klasyfikacyjny, czyli algorytm prowadzący do przyporządkowania obiektom odpowiednich etykiet na podstawie charakteryzujących je cech, rozpatrywany z punktu widzenia modelowania cyfrowego, jest zadaniem związanym z budową struktury sterującej przetwarzaniem informacji. Niezbędne dane mogą pochodzić z rejestracji zachodzących procesów, a w przypadku danych przestrzennych ich źródłem może być digitalizacja materiałów kartograficznoglebowych, siedliskowych i topograficznych. Naturalnym kandydatem do rozwiązania zadań klasyfikacyjnych, czyli konstruowania systemu przetwarzającego odzwierciedlającego prawidłowości klasyfikacji są algorytmy mieszczące się w obrębie tak zwanej inteligencji obliczeniowej. Jej domeną są zadania, które na gruncie algorytmiki deterministycznej nie mają efektywnego rozwiązania.

\section{Problem klasyfikacyjny. Cel badań}

Problemy klasyfikacyjne polegają na wykrywaniu związków przyczynowo-skutkowych między cechami obiektów (w najszerszym znaczeniu tego słowa) a ich pozycją $\mathrm{w}$ systemie klasyfikacyjnym wyrażaną za pomocą nominalnej etykiety. Cechy obiektów mogą mieć naturę ciagłą lub dyskretną, mogą być zmiennymi porządkowymi, a także nominalnymi (etykietami cechy). Przestrzeń cech może być bardzo zróżnicowana obejmując różne warianty ich opisu. Centralnym założeniem rozwiązywania problemów klasyfikacyjnych jest istnienie związku między konfiguracją wartości cech (wektorem cech) i etykietami (klasami) obiektów. Związek ten może być identyfikowany przy wykorzystaniu algorytmu deterministycznego (np. liniowe funkcje dyskryminacyjne Fishera) lub iteracyjnego, z losową inicjalizacją modelu. Literatura dotycząca teoretycznych i praktycznych aspektów klasyfikacji jest bardzo obszerna i systematycznie się powiększa, np. Kurzyński (1997), Tadeusiewicz (1993).

Częściowo losowy charakter różnych algorytmów ustalania reguł klasyfikacji, a także statystyczna zmienność cech obiektów i błędy obserwacji, powodują, że prowadzą one często do modeli tylko częściowo zadowalających, obciążonych pewnym marginesem błędu, identyfikowanym ilościowo w procesie walidacji. Czynnikiem zmniejszającym poprawność modeli są braki w wektorze cech charakteryzujących obiekt. Każda dodatkowa informacja przydatna w klasyfikacji obiektów podnosi jej koszty, wymaga też czasu niezbędnego na jej uzyskanie. $Z$ tego powodu najtańszym sposobem pozyskiwania danych do budowy modeli klasyfikacji jest skorzystanie $\mathrm{z}$ istniejących danych (rejestr transakcji rynkowych, dane giełdowe, dokumentacja gleb i siedlisk) lub informacji gromadzonych na potrzeby bieżącej działalności (handel, usługi, warunki meteorologiczne).

Celem prezentowanych badań jest ocena przydatności niektórych algorytmów klasyfikacyjnych do budowy modeli przydatnych $\mathrm{w}$ szacowaniu związku warunków fizjograficznych i klasyfikacji kompleksów użytkowej klasyfikacji gleb. W szczególności celem było uzyskanie oceny stopnia użyteczności danych pochodzących z digitalizacji materiałów kartograficzno-glebowych i topograficznych do konstruowania użytecznych modeli klasyfikujących kompleksy przydatności rolniczej gleb, przydatności do tego celu różnych algorytmów z zakresu inteligencji obliczeniowej oraz możliwości poprawy stopnia generalizacji przez wykorzystanie zespołów modeli. Dane wykorzystane $\mathrm{w}$ badaniach pochodziły wyłącznie $\mathrm{z}$ digitalizacji istniejących materiałów kartograficzno-glebowych. Należy podkreślić, iż jest to jedna z możliwych, przypuszczalnie podstawowa, metoda konstruowania baz danych przestrzennych o glebach, proponowanych przez autorów koncepcji cyfrowej kartografii gleb. 


\section{Dane}

Najpewniejszym, zarazem najbardziej kosztownym i czasochłonnym sposobem budowy bazy danych fizjograficzno-glebowych są bezpośrednie obserwacje w odpowiednio gęstej sieci opróbowania. $\mathrm{Na}$ dużych obszarach zapewnienie odpowiedniej gęstości obserwacji byłoby kosztowne i czasochłonne, nawet przy zastosowaniu metod zdalnych (dostarczających zwykle danych wymagających interpretacji, częściowo błędnych). $Z$ tego powodu rozsądnym założeniem wydaje się postulat wykorzystania digitalizacji istniejących materiałów. Wprowadza to do modelu klasyfikacyjnego dodatkowy błąd związany z niedoskonałościami odwzorowania kartograficznego, subiektywizmem $\mathrm{w}$ rozgraniczeniu konturów, generalizacją cech itp. Pozytywną stroną tego rozwiązania jest możliwość skorzystania $\mathrm{z}$ istniejących modeli DTM, baz danych hydrograficznych i hydrogeologicznych.

W opisywanych badaniach wykorzystane zostały dane pochodzące $\mathrm{z}$ digitalizacji map glebowo-rolniczych rejonu Górnośląskiego Okręgu Przemysłowego w skali 1:25 000. Identyfikowaną zmienną zależną był kompleks przydatności rolniczej gleb. Zmiennymi objaśniającymi ( 16 zmiennych) były: rzędna terenu, średnie zawartości frakcji spławialnej i pyłowej utworów macierzystych grup mechanicznych gleb w warstwach: 0-25 cm, 25-75 cm, 75-125 cm, >125 cm (łącznie 8 zmiennych), wskaźnik konfiguracji terenu związany z oceną stopnia sprzyjania ukształtowania terenu odpływowi powierzchniowemu, użyt- kowanie gruntu (zmienna nominalna), nachylenie terenu, wskaźnik położenia wody gruntowej modelowany na podstawie rzędnych linii brzegowych cieków i zbiorników wodnych, odległość od brzegów cieków i zbiorników wodnych.

Należy podkreślić, że analogowa mapa gleboworolnicza jest nośnikiem o relatywnie niskiej wartości informacyjnej. Wynika to między innymi ze stopnia generalizacji informacji morfologicznych, mało precyzyjnego określenia grup mechanicznych oraz stopnia generalizacji informacji typologicznej.

Na obszarze GOP, wyodrębniono prostokątny obszar o rozmiarach $59 \mathrm{~km}$ (kierunek WE) na $44 \mathrm{~km}$ (kierunek NS) wyróżniono 6490000 kwadratowych płatów terenu (pikseli) o powierzchni $400 \mathrm{~m}^{2}(20 \times$ $20 \mathrm{~m}$ ). Pełna informacja glebowa terenów rolniczych była w tym obszarze dostępna dla 2776890 pikseli. Pozostały teren stanowiły obszary zabudowane, tereny leśne, nieużytki oraz tereny komunikacyjne.

$\mathrm{Z}$ zestawienia w tabeli 1 wynika, że statystycznie rzecz ujmując, w analizowanym obszarze terenów użytkowanych rolniczo dominują grunty orne średnie i słabe, choć zauważa się dość znaczny (ponad 17\%) udział gruntów ornych dobrych (kompleks 2). Reprezentowane są prawie wszystkie kompleksy gruntów ornych (brak kompleksu pszennego bardzo dobrego). W obrębie trwałych użytków zielonych (nieznacznie więcej niż $21 \%$ udziału) dominują użytki średnie (2z), oraz słabe i bardzo słabe (3z), ze sporadycznym udziałem użytków bardzo dobrych i dobrych $(1 \mathrm{z}-$ ok. $0,06 \%)$.

TABELA 1. Liczba elementów jednostek kompleksów przydatności rolniczej i typów gleb w zbiorze danych wylosowanych z bazy danych GOP. Pojedyncza jednostka jest kwadratem o powierzchni 4 arów

TABLE 1 . The number of pieces of soil capability index in the data set drawn from the database of the GOP. A single unit is a square with an area of 4 acres

\begin{tabular}{|c|c|c|c|c|c|c|c|c|c|c|c|c|}
\hline KOMP & $\mathrm{Bd}$ & A & B & D & Etm & $\mathrm{F}$ & $\mathrm{G}$ & $\mathrm{R}$ & M & $\mathrm{Tn}$ & $\mathrm{Tz}$ & Ogółem \\
\hline K 2 & 11 & 11585 & 4402 & 94 & 15 & 108 & 1 & 1035 & 0 & 3 & 174 & 17428 \\
\hline $\mathrm{K}_{-}^{-} 3$ & 2 & 544 & 1433 & 16 & 7 & 20 & 1 & 5671 & 0 & 0 & 82 & 7776 \\
\hline $\mathrm{K}_{4}^{-} 4$ & 7 & 4229 & 3218 & 60 & 15 & 22 & 3 & 160 & 0 & 7 & 68 & 7789 \\
\hline $\mathrm{K} \_5$ & 5 & 3667 & 9445 & 137 & 35 & 94 & 0 & 1481 & 9 & 5 & 171 & 15049 \\
\hline K_6 & 11 & 2322 & 13235 & 346 & 85 & 293 & 0 & 1831 & 4 & 7 & 252 & 18386 \\
\hline $\mathrm{K}_{-}^{-} 7$ & 0 & 232 & 2650 & 28 & 7 & 112 & 1 & 38 & 28 & 3 & 67 & 3166 \\
\hline K_8 & 3 & 4014 & 817 & 876 & 17 & 259 & 0 & 38 & 1 & 1 & 102 & 6128 \\
\hline K_9 & 0 & 1164 & 162 & 1618 & 11 & 225 & 12 & 5 & 81 & 3 & 41 & 3322 \\
\hline$Z_{-}^{-} 1$ & 0 & 0 & 0 & 0 & 0 & 62 & 0 & 0 & 0 & 0 & 0 & 62 \\
\hline$Z_{-}^{-} 2$ & 17 & 313 & 3693 & 4914 & 2443 & 2961 & 30 & 56 & 453 & 759 & 205 & 15844 \\
\hline Z_3 & 15 & 123 & 984 & 1153 & 899 & 894 & 5 & 101 & 1058 & 347 & 135 & 5714 \\
\hline Ogółem & 71 & 28193 & 40039 & 9242 & 3534 & 5050 & 53 & 10416 & 1634 & 1135 & 1297 & 100664 \\
\hline
\end{tabular}

Objaśnienia skrótów: KOMP - kompleks rolniczej przydatności gleb, Bd - brak danych dotyczących typologii gleb, A - gleby bielicowe, B - gleby brunatne, D - czarne ziemie, Etm - gleby mułowo-błotne, F - mady, G - gleby glejowe, R - rędziny, M - gleby murszowe, Tn - gleby torfowe, Tz-tereny zabudowane.

Abbreviations: KOMP - soil capabilty unit, Bd - no data, A - podsols, B - brown soils, D - black earth, Etm - muddy soil, F - alluvial soils, G - soil glial, $\mathrm{R}$ - rendzinas, $\mathrm{M}$ - muck soils, $\mathrm{Tn}$ - peaty, $\mathrm{Tz}$ - built-up areas. 
Ocena typologiczno-glebowa nie jest w pełni wiarygodna $z$ uwagi na znane słabości map glebowo-rolniczych w tym względzie. Utrzymując się w jej konwencji największy jest udział gleb brunatnych (blisko 40\%) i bielicowych (ponad 28\%). Dokumentacja wskazuje na stosunkowo wysoki udział czarnych ziem (blisko 10\%) oraz rędzin (ponad 10\%).

Dla celów podjętych badań wylosowano z posiadanej bazy danych liczący 100664 rekordów podzielony następnie losowo na dwie części: liczący 33218 rekordów zbiór uczący (w algorytmach optymalizacyjnych dzielony następnie na część uczącą i testową w proporcji $2: 1$ ) oraz walidacyjny złożony z pozostałych rekordów danych.

\section{Algorytmy klasyfikacji i ich oprogramowanie}

Klasyfikacyjny (w sensie statystycznym) model kartograficzny pokrywy glebowej może być rozumiane na dwa sposoby:

1. Jako odwzorowanie relacji przestrzennych między konturami klasyfikacyjnymi. Produktem modelu jest projekcja zarejestrowanego w przeszłości obrazu rozmieszczenia jednostek klasyfikacyjnych. Obraz cyfrowy jest w tym przypadku odzwierciedleniem mapy analogowej, zaś algorytm klasyfikacji ma charakter pamięci.

2. Jako wyselekcjonowany $z$ danych (model oparty na danych) zbiór reguł, zazwyczaj mających postać „czarnej skrzynki”, interpretujących konfigurację zmiennych opisujących obiekt (np. piksel obrazu, element rastra) i przyporządkowujący jej etykietę klasyfikacji.

Pierwszy z modeli może być przydatny w bieżących zastosowaniach lecz odległy od przydatności w predykcji przyszłego stanu gleb. Drugie podejście pozwala na predykcję kierunków zmian klasyfikacji (upodabnianie się warunków do właściwych dla konkretnej klasy), jeżeli model charakteryzuje wystarczająca zdolność generalizacji (Tadeusiewicz 1993).

Klasyfikacja danych wymaga przeprowadzenia optymalizacji modelu, polegającej na ekstrakcji reguł logicznych, zdefiniowanych jawnie lub niejawnie (czarna skrzynka). Proces taki nazywa się treningiem (uczeniem), zaś warunkiem jego poprawnego przebiegu jest wykorzystanie odpowiednio dużego, reprezentatywnego zbioru poprawnie sklasyfikowanych danych. Trening prowadzi do adaptacyjnego (ewolucyjnego) utworzenia struktury sterującej przetwarzaniem danych wejściowych; jeżeli reguły klasyfikacji zostały ustalone poprawnie $\mathrm{w}$ procesie treningu, wprowadzenie do modelu innych danych, spoza zbioru treningowego powinno zapewniać poprawną klasyfikację opisywanego przez nie obiektu.
Brak zdefiniowanych deterministycznych zależności klasyfikacyjnych, odwołujących się do cech pochodzących z danych kartograficzno-glebowych, jak też immanentne cechy algorytmów klasyfikacji, generują błędy klasyfikacji. Przyjmując zbiór czynników charakteryzujących obiekt klasyfikacji jako wielowymiarową przestrzeń cech, z punktu widzenia użytkownika - przynajmniej w niektórych przypadkach, błędy klasyfikacji mogą być uznane za wynik niedoskonałości konkretnego algorytmu. Pośrednio oznacza to, że inny algorytm może w obszarze błędów alternatywnego algorytmu, działać lepiej. Celem badań nie było jednak uzyskanie konkretnego, uniwersalnego modelu klasyfikacji kompleksów na podstawie danych kartograficzno-glebowych. Oczekiwanym wynikiem było oszacowanie możliwości modelowania zróżnicowania kompleksów rolniczej przydatności gleb na podstawie ograniczonych informacji charakteryzujących morfologię terenu, ich położenie i uziarnienie.

Lista adaptacyjnych algorytmów klasyfikacyjnych jest obszerna. Różnią się one architekturą tworzonych modeli, sposobem działania, w większości wymagaja także subiektywnych decyzji dotyczących niezbędnych parametrów sterujących przebiegiem ich optymalizacji (współczynniki uczenia, momentu, współczynniki regularyzacji, głębokość i liczba drzew decyzyjnych itp.). Nawet przy identycznych wartościach startowych algorytmów optymalizacji, losowy dobór parametrów inicjalizacji prowadzi do różniących się modeli. W badaniach wykorzystano różne algorytmy, choć trudno mówić o wyczerpaniu listy potencjalnych możliwości w tym zakresie. Każdy z algorytmów został uruchomiony w celu optymalizacji na podstawie zbioru danych treningowych kilka razy, w celu ustalenia architektury, której wzrost nie powodował istotnej poprawy zdolności identyfikacji. Takie postępowanie, metodą prób i błędów, jest uzasadnione brakiem metodologii pozwalającej na wybór architektury najlepszej dla określonego zadania. Wynik przedstawiony w dalszej części pracy dotyczy najkorzystniejszego rezultatu z punktu widzenia kryterium walidacji. Listę wykorzystanych algorytmów tworzą wymienione niżej modele.

MLP100 (StatSoft). Algorytm MLP (MultiLayer Perceptron) jest reprezentantem algorytmu sieci neuronowych z nielokalnymi funkcjami transferu, co oznacza ograniczenie wyjść jednostek przetwarzających co do wartości (zazwyczaj $[0 ; 1]$ lub $[-1 ; 1]$ ), oraz brak ograniczenia co do zasięgu w przestrzeni cech (asymptotyczne dążenie funkcji transferu do wartości granicznych). W obliczeniach wykorzystany został moduł firmy StatSoft zawarty w pakiecie Statistica składający się z jednostek sigmoidalnych 
w warstwie ukrytej. Algorytm MLP jest jednym z najczęściej wykorzystywanych modeli danych klasyfikacyjnych, często błędnie utożsamiany z sieciami neuronowymi w ogóle (Tadeusiewicz 1993).

DL [200 200 RectifierLU] H2O. Wykorzystano moduł DeepLearning, analogiczny do MLP, jednak $\mathrm{z}$ odmiennymi funkcjami transferu (Rectifier Linear Unit). Funkcja RLU nie ma górnego ograniczenia wartości. Algorytm udostępniony w projekcie o nazwie $\mathrm{H} 2 \mathrm{O}$, na stronie Oxdata.com, w połączeniu $\mathrm{z}$ oprogramowaniem klienckim $\mathrm{H} 2 \mathrm{O}$ Flow w języku Java. Jest to model tradycyjnie zaliczany do metodologii tak zwanego głębokiego uczenia (deep learning), związanego ze stosowaniem więcej niż jednej warstwy ukrytej w strukturze przetwarzającej (LeCun et al. 2015, Zhou et al. 2006).

DL750 [750 750 RectifierLU L1 L2] H2O. Algorytm analogiczny do poprzedniego, ze zwiększonym rozmiarem warstw ukrytych, z regularyzacją L1 i L2. Regularyzacja zabezpiecza algorytm przed efektem nadmiernego dopasowania (overfitting) poprzez usuwanie połączeń o bardzo dużych i bardzo małych wartościach.

SVM (GhostMiner). Algorytm Maszyny Wektorów Wspierających (SVM - Support Vector Machines) w implementacji pakietu GhostMiner firmy FQS Fujitsu Poland. Wynik modelowania klasyfikacji pominięto w dalszej części, z powodu wyjątkowo dużego udziału wskazań typu „brak jakiejkolwiek identyfikacji" (36,9\% przypadków). Algorytm o architekturze zbudowanej z jednostek RBF (Radial Basis Functions), czyli z tak zwanymi lokalnymi funkcjami transferu. Funkcja ta charakteryzuje się wartością istotnie różną od zera $\mathrm{w}$ ograniczonej przestrzeni cechy. Z uwagi na szczególny sposób tworzenia zbioru jednostek RBF, chętnie wykorzystywany w problemach klasyfikacyjnych i regresyjnych. Jego charakterystyczną cechą jest ograniczenie liczby jednostek RBF w wyniku uwzględniania tylko jednostek bliskich granicy klas. W analizowanym przypadku zawiódł, generując wiele wskazań pustych (klasyfikacja nieznana), zapewne z powodu stosunkowo znacznej liczby klas (Cortes and Vapnik 1995).

SSV tree (GhostMiner). Algorytm Separability of Split Value budowy drzewa decyzyjnego w implementacji pakietu GhostMiner firmy FQS Fujitsu Poland. Algorytm nie-neuronowy, tworzący obszerny zbiór reguł prowadzących do nadania odpowiedniej etykiety. Pod względem funkcjonalnym najbardziej zbliżony do tradycyjnego wnioskowania klasyfikacyjnego (Jankowski 2003).

FSM (GhostMiner). Algorytm ontogeniczny Feature Space Mapping, analogiczny do systemów neuro-rozmytych, zbudowany z jednostek typu RBF.
Implementacja w pakiecie GhostMiner firmy FQS Fujitsu Poland. Algorytm polegający na iteracyjnym dostosowaniu struktury (liczby jednostek ukrytych) do złożoności przestrzeni cech. Jednostki włączane i usuwane ze struktury w procedurze optymalizacji są typu RBF (Duch and Diercksen 1995).

IncNet (GhostMiner). Algorytm IncNet prowadzący do zespołu klasyfikatorów identyfikujących pojedyncze klasy. Implementacja w pakiecie GhostMiner firmy FQS Fujitsu Poland (Jankowski 2003).

GBM (H2O). Algorytm Gradient Boosting Machines, bazujący na budowie wielu drzew decyzyjnych o niskiej przydatności klasyfikacyjnej (Friedman 2000). Algorytm udostępniony jako projekt o nazwie $\mathrm{H} 2 \mathrm{O}$, na stronie Oxdata.com, w połączeniu z oprogramowaniem klienckim H2O Flow w języku Java. Algorytm reprezentujący koncepcję wykorzystania dużego zbioru słabych klasyfikatorów do poprawnej klasyfikacji.

DRF (H2O). Algorytm DRF (Distributed Random Forest) obejmuje wiele drzew decyzyjnych bazujących na zróżnicowaniu poszczególnych atrybutów (Kleinberg 1996). Wskazanie klasyfikacji odbywa się na zasadzie głosowania. Algorytm udostępniony jako projekt o nazwie $\mathrm{H} 2 \mathrm{O}$, na stronie Oxdata.com, w połączeniu z oprogramowaniem klienckim $\mathrm{H} 2 \mathrm{O}$ Flow w języku Java.

SAE (Neural Network MATLAB Toolbox) skonstruowany w oparciu o Neural Network Toolbox (Palm 2012). Algorytm zaliczany do typu deep learning, zdający egzamin w zadaniach klasyfikacji pisma ręcznego i głosu. Cechą charakterystyczną algorytmu jest częściowa inicjalizacja w trybie nienadzorowanym (bez udziału danych etykietowanych). Zostają one następnie wykorzystane do douczania precyzyjnego w drugim kroku optymalizacji.

Niektóre algorytmy i pakiety programowe dla prawidłowego działania wymagaja transformowania zmiennych, w większości przypadków przez ich normalizację w przedziale wartości $0-1$. Niektóre pakiety stosują tę operację domyślnie (Statistica), inne z wyboru użytkownika (GhostMiner), pozostałe wymagają normalizacji zmiennych przed wczytaniem danych.

\section{WYNIKI}

Zbiór treningowy złożony z 33218 danych został wykorzystany do optymalizacji wymienionych algorytmów klasyfikacyjnych. Wskaźnikiem poprawności działania zoptymalizowanego klasyfikatora jest wynik klasyfikacji zbioru walidacyjnego (67 465 przypadków). Wyniki klasyfikacji zbioru walidacyjnego przez poszczególne algorytmy zawiera tabela 2 . 
TABELA 2. Zestawienie procentowej poprawności wskazań kompleksów przydatności rolniczej zbioru walidacyjnego zoptymalizowanych modeli klasyfikacyjnych

TABLE 2. The percentage of correctness of indications soil suitability units of the validation set of classification models

\begin{tabular}{lccccccccc}
\hline KOMP & DL & DL750 & DRF & GBM & SSVtree & IncNet & MLP100 & FSM & SAE \\
\hline K_2 & 87,2 & 91,6 & 93,5 & 89,4 & 83,1 & 85,8 & 85,1 & 87,3 & 84,8 \\
\hline K_3 & 78,9 & 75,8 & 87,5 & 82,2 & 71,6 & 72,1 & 79,1 & 80,6 & 71,6 \\
\hline K_4 & 57,4 & 53,6 & 82,9 & 70,9 & 50,1 & 2,7 & 67,4 & 71,5 & 62,8 \\
\hline K_5 & 68,4 & 70,2 & 90,9 & 87 & 78 & 28,5 & 81,3 & 78,8 & 79,4 \\
\hline K_6 & 80,6 & 80,6 & 88,3 & 81,1 & 79,4 & 77,3 & 80,5 & 80,2 & 77,2 \\
\hline K_7 & 87,4 & 64,1 & 92,3 & 91,1 & 83,8 & 0,3 & 83,9 & 80,6 & 83,1 \\
\hline K_8 & 7,4 & 0 & 60 & 34,8 & 31,5 & 1,5 & 34,1 & 48,8 & 21 \\
\hline K_9 & 10,5 & 0,7 & 42,6 & 24,9 & 12,6 & 0,1 & 21,8 & 29,6 & 12,1 \\
\hline Z_1 & 0 & 0 & 100 & 100 & 100 & 85 & 0 & 95 & 0 \\
\hline Z_2 & 96 & 99,1 & 97 & 94,5 & 78,5 & 99,9 & 93,1 & 90,2 & 93,6 \\
\hline Z_3 & 31,7 & 7 & 65,1 & 46,5 & 43,2 & 0,3 & 51,8 & 55,3 & 39,4 \\
\hline Lacznie & 71 & 69 & 86 & 78,5 & 69,8 & 54,9 & 75,9 & 77,1 & 72,2 \\
\hline
\end{tabular}

W tabeli 2 ujęto procent poprawnych wskazań jednostek poszczególnych kompleksów w stosunku do liczebności odpowiedniej klasy zbioru walidacyjnego. Ostatni wiersz zawiera procent poprawnych wskazań w stosunku do całości zbioru. W tabeli zaznaczono komórki z najlepszymi i najgorszymi wynikami wskazań.

Wyniki walidacji są silnie zróżnicowane. Analizując poprawność identyfikacji poszczególnych kompleksów można dostrzec, że największe problemy dotyczą wyodrębniania kompleksów K_8, K_9, Z_1 i Z 3. Najlepsze algorytmy poprawnie identyfikuja niespełna $47 \%$ jednostek K_9 oraz $60 \%$ K_8. Najgorsze pod tym względem są algorytmy IncNet oraz DL i DL750, których wynik nie przekracza na ogół $10 \%$ poprawnych identyfikacji tych jednostek. Podobny problem dotyczy kompleksu Z_ 3, choć nawet występujący w śladowych ilościach kompleks $Z$ _1 jest identyfikowany bardzo poprawnie przez niektóre algorytmy (np. DRF, GBM, SSV tree, nieco gorzej przez FSM i IncNet), co wskazuje, że jest on dostatecznie odmienny fizjograficznie od innych kompleksów (w sensie wykorzystanych danych).

Wykorzystane algorytmy nie są porównywalne. Różnią się subiektywnie zdefiniowaną architektura, liczbą parametrów i ograniczeniami zdefiniowanymi a priori (kryterium stopu algorytmu). Odchodząc jednak od zamiaru oceny algorytmów jako takich, można jednak wskazać wśród nich modele o najkorzystniejszych właściwościach, z punktu widzenia walidacji. Liczący ponad 67 tysięcy przypadków zbiór walidacyjny jest zapewne dobrą podstawą do obiektywnej oceny konkretnych modeli. $\mathrm{Z}$ tego punktu widzenia najkorzystniej wypada algorytm DRF: ma on największy wskaźnik poprawnych identyfikacji elementów całości zbioru, jak też góruje nad pozostałymi pod względem poprawności identyfikacji poszczególnych kompleksów; jest tylko nieznacznie gorszy pod względem rozpoznawalności kompleksu Z_2 (97\%) od algorytmu IncNet (99,9\%), który jednak zawodzi pod względem każdego innego kryterium. Porównywalne, choć nieco gorsze od DRF wyniki, daja algorytmy GBM (78,5\% poprawnych wskazań) oraz FSM (77,1\% poprawnych wskazań). Obydwa te modele $\mathrm{z}$ większą lub mniejszą skutecznością identyfikują wszystkie jednostki klasyfikacji występujące w zbiorze (najgorszy wynik GBM to 24,9\% kompleksu K_9, podobnie zreszta jak w przypadku FSM, który poprawnie identyfikuje 29,6\% przypadków tego kompleksu).

Problemem niskiej identyfikowalności niektórych klas obiektów (kompleksów) jest automatyczne pogorszenie wskazań innych kompleksów, do których są błędnie zaliczane wadliwie zaklasyfikowane jednostki.

Względnie największy procent błędnych, negatywnych wskazań dotyczy kompleksów wyróżnianych jako K_8 i K_9. Łącznie w zbiorze walidacyjnym jest ich 6304 (odpowiednio 4042 i 2262, ogólnie nieco mniej niż $10 \%$ zbioru). Znaczna liczba nietrafnych wskazań skutkuje także wzrostem błędnych pozytywnych wskazań innych kompleksów. Analizując rozkład wskazań kompleksu K_8 przez poszczególne algorytmy (tab. 3) łatwo zauważyć, że najczęściej błędnie wskazywanym kompleksem (w rzeczywistości odpowiadający warunkom kompleksu K_8) jest, w znacznym stopniu jego odpowiednik litologiczny, kompleks K_2. Większość algorytmów (wy- 
TABELA 3. Procentowy rozkład wskazań kompleksów K_8 i K_9 przez poszczególne algorytmy.

TABLE 3. Percentage distribution of indications soil capability units $\mathrm{K} \_8$ and $\mathrm{K} \_9$ by different algorithms

\begin{tabular}{|c|c|c|c|c|c|c|c|c|c|c|}
\hline \multirow{2}{*}{$\begin{array}{l}\text { Algorytm } \\
\text { Algorithm }\end{array}$} & \multirow{2}{*}{$\begin{array}{l}\text { Kompleks } \\
\text { Soil unit }\end{array}$} & \multicolumn{2}{|c|}{ Wskazany kompleks } & \multicolumn{2}{|c|}{ Soil unit indicated } & \multirow[b]{2}{*}{ K_6 } & \multirow[b]{2}{*}{ K_7 } & \multirow[b]{2}{*}{ K_8 } & \multirow[b]{2}{*}{ K_9 } & \multirow[b]{2}{*}{ Z_3 } \\
\hline & & K_2 & K_3 & K_4 & K_5 & & & & & \\
\hline $\mathrm{DL}$ & $\begin{array}{l}\text { K_8 } \\
\text { K_9 }\end{array}$ & $\begin{array}{r}69,5 \\
0,5\end{array}$ & $\begin{array}{l}2,7 \\
0,2\end{array}$ & $\begin{array}{r}11,3 \\
0,4\end{array}$ & $\begin{array}{r}6,7 \\
21,3\end{array}$ & $\begin{array}{c}2,2 \\
50,6\end{array}$ & $\begin{array}{r}0,1 \\
16,5\end{array}$ & $\begin{array}{l}7,4 \\
0\end{array}$ & $\begin{array}{r}0,1 \\
10,5\end{array}$ & $\begin{array}{l}0 \\
0\end{array}$ \\
\hline DL750 & $\begin{array}{l}\text { K_8 } \\
\text { K_9 }\end{array}$ & $\begin{array}{c}76,7 \\
0,6\end{array}$ & $\begin{array}{l}2,7 \\
0,2\end{array}$ & $\begin{array}{r}10,9 \\
0,2\end{array}$ & $\begin{array}{r}7,5 \\
25,1\end{array}$ & $\begin{array}{r}2,1 \\
66,1\end{array}$ & $\begin{array}{l}0 \\
7,1\end{array}$ & $\begin{array}{l}0 \\
0\end{array}$ & $\begin{array}{l}0 \\
0,7\end{array}$ & $\begin{array}{l}0 \\
0\end{array}$ \\
\hline DRF & $\begin{array}{l}\mathrm{K} \_8 \\
\mathrm{~K} \_9 \\
\end{array}$ & $\begin{array}{r}30,8 \\
0,4 \\
\end{array}$ & $\begin{array}{l}0,9 \\
0 \\
\end{array}$ & $\begin{array}{l}5,2 \\
0,3 \\
\end{array}$ & $\begin{array}{r}2,2 \\
16,5 \\
\end{array}$ & $\begin{array}{r}0,6 \\
33,2 \\
\end{array}$ & $\begin{array}{l}0 \\
6,7 \\
\end{array}$ & $\begin{array}{c}60 \\
0,3 \\
\end{array}$ & $\begin{array}{c}0,2 \\
42,6\end{array}$ & $\begin{array}{l}0 \\
0\end{array}$ \\
\hline GBM & $\begin{array}{l}\mathrm{K} \_8 \\
\mathrm{~K} \_9 \\
\end{array}$ & $\begin{array}{c}49,7 \\
1,1 \\
\end{array}$ & $\begin{array}{l}1,5 \\
0 \\
\end{array}$ & $\begin{array}{l}7,5 \\
1,1 \\
\end{array}$ & $\begin{array}{r}5,9 \\
23,4 \\
\end{array}$ & $\begin{array}{r}0,5 \\
38,1 \\
\end{array}$ & $\begin{array}{c}0 \\
10,4 \\
\end{array}$ & $\begin{array}{c}34,8 \\
1 \\
\end{array}$ & $\begin{array}{c}0 \\
24,9\end{array}$ & $\begin{array}{l}0 \\
0\end{array}$ \\
\hline SSVTree & $\begin{array}{l}\text { K_8 } \\
\text { K_9 }\end{array}$ & $\begin{array}{r}52,1 \\
0,7\end{array}$ & $\begin{array}{l}2 \\
0,3\end{array}$ & $\begin{array}{l}6,8 \\
1,9\end{array}$ & $\begin{array}{r}6,6 \\
25,1\end{array}$ & $\begin{array}{c}0,9 \\
43,8\end{array}$ & $\begin{array}{c}0 \\
14,2\end{array}$ & $\begin{array}{r}31,5 \\
1,3\end{array}$ & $\begin{array}{c}0 \\
12,6\end{array}$ & $\begin{array}{l}0 \\
0,1\end{array}$ \\
\hline IncNet & $\begin{array}{l}\mathrm{K} \_8 \\
\mathrm{~K} \_9 \\
\end{array}$ & $\begin{array}{c}75,2 \\
1,4 \\
\end{array}$ & $\begin{array}{l}0,1 \\
0,1 \\
\end{array}$ & $\begin{array}{l}1,8 \\
0,2 \\
\end{array}$ & $\begin{array}{r}9,1 \\
17,7 \\
\end{array}$ & $\begin{array}{l}12,3 \\
80,5 \\
\end{array}$ & $\begin{array}{l}0 \\
0 \\
\end{array}$ & $\begin{array}{l}1,5 \\
0 \\
\end{array}$ & $\begin{array}{l}0 \\
0,1 \\
\end{array}$ & $\begin{array}{l}0 \\
0 \\
\end{array}$ \\
\hline MLP100 & $\begin{array}{l}\mathrm{K} \_8 \\
\mathrm{~K} \_9\end{array}$ & $\begin{array}{c}47,1 \\
0,6\end{array}$ & $\begin{array}{l}2,2 \\
0,1\end{array}$ & $\begin{array}{r}10,3 \\
1,1 \\
\end{array}$ & $\begin{array}{c}5,1 \\
21,2\end{array}$ & $\begin{array}{r}0,8 \\
43,9\end{array}$ & $\begin{array}{c}0 \\
10,7\end{array}$ & $\begin{array}{r}34,1 \\
0,5 \\
\end{array}$ & $\begin{array}{r}0,4 \\
21,8 \\
\end{array}$ & $\begin{array}{l}0 \\
0\end{array}$ \\
\hline
\end{tabular}

jątkiem jest DRF i w mniejszym stopniu FSM), generuje blisko lub ponad 50\% wskazań jednostek K 8 jako K_2. Podobieństwo litologiczne jest przypuszczalnie decydującym czynnikiem, powodującym, że dominujący ilościowo kompleks $\mathrm{K} \_2$ jest częściej, błędnie wskazywany także wśród jednostek K_8.

\section{Uzupełnienie wektora danych}

Skromna, pod względem zakresu informacji, baza danych wystarcza do uzyskania poprawności klasyfikacji sięgającej $86 \%$ danych. Kwestią do dyskusji jest stopień akceptacji takiego wyniku. Można jednak podjąć próbę jego poprawy przez wzrost zakresu danych wejściowych oraz zastosowania bardziej złożonych technik eksploracji.

Należy zwrócić uwagę, że dane obejmują dość znaczny i stosunkowo zróżnicowany morfologicznie obszar. Rzędna terenu ma w tym przypadku umiarkowaną wartość informacyjna. Znaczenie dla oceny położenia konkretnego punktu terenu ma nie tylko jego rzędna lecz także relacja do rzędnych większego otoczenia. Można przypuszczać, że dołączenie do wektora danych wejściowych informacji o współrzędnych poziomych może poprawić wartość informacyjną rzędnej terenu, tworząc kontekst związany z położeniem. Automatycznie, wobec wprowadzenia danych lokalizacyjnych, pojawia się ryzyko doprowadzenia do nadmiernego dopasowania modelu do danych (overfitting - zapamiętanie danych, niski poziom generalizacji obserwacji), lecz to zagrożenie może być kontrolowane przez regularyzację lub inne techniki chroniące przed tym zjawiskiem, zaś obiektywną ocenę umożliwia walidacja modelu. Tabela 4 prezentuje charakterystykę (dane walidacyjne) modeli uzyskanych po tym uzupełnieniu. Dane walida-

TABELA 4. Zestawienie procentowej poprawności wskazań kompleksów przydatności rolniczej zbioru walidacyjnego zoptymalizowanych modeli klasyfikacyjnych. Wektor wejściowy uzupełniony o współrzędne

TABLE 4. Percentage of correctness of indications soil suitability units of the validation set of classification models. Input vector supplemented by coordinates

\begin{tabular}{lcllllllll}
\hline KOMP & DL & DL750 & GBM & DRF & SSVtree & IncNet & FSM & MLP79 & SAE \\
\hline K_2 & 82,7 & 87,5 & 91,3 & 95,2 & 85,9 & 94,1 & 87,7 & 87 & 83,3 \\
K_3 & 74,4 & 82,1 & 85,4 & 89,7 & 77,5 & 72,2 & 83,3 & 83,2 & 75,4 \\
K_4 & 62,6 & 71 & 77,8 & 89,6 & 58,2 & 0 & 77,8 & 75 & 60,1 \\
K_5 & 85,5 & 84 & 87,1 & 92 & 76,4 & 0 & 81,2 & 82 & 80,9 \\
K_6 & 82,7 & 80,3 & 85,7 & 91,4 & 81,8 & 87,5 & 83,8 & 82,9 & 72 \\
K_7 & 85,8 & 91,4 & 89,9 & 91,6 & 86,6 & 0 & 84,9 & 88,2 & 60,7 \\
K_8 & 46,4 & 43,1 & 56,8 & 73,4 & 39 & 0,7 & 58,7 & 52,2 & 33,3 \\
K_9 & 54,7 & 46,6 & 66,6 & 78,9 & 35,5 & 0 & 63,7 & 63,9 & 35 \\
Z_1 & 100 & 0 & 92,9 & 97,6 & 100 & 0 & 92,9 & 97,6 & 0 \\
Z_2 & 90,5 & 87,7 & 96,3 & 97,7 & 84,3 & 96,3 & 95,3 & 91,3 & 95,9 \\
Z_3 & 57,9 & 0 & 58,7 & 79,1 & 54 & 14,6 & 57,5 & 66,9 & 34,2 \\
\hline Razem & 77,9 & 75,2 & 84,3 & 90,8 & 74,5 & 54,2 & 81,9 & 81,1 & 72,4 \\
Total & & & & & & & & \\
\hline
\end{tabular}


cyjne wskazują na poprawę stopnia identyfikacji kompleksów przez modele (wyjątkiem są IncNet i SAE). W dalszym ciagu najlepszy wynik wykazuje model DRF (blisko 91\%), poprawa wskazań innych modeli siega kilku procent.

\section{Zespół klasyfikatorów}

Immanentne braki indywidualnych algorytmów klasyfikacyjnych zwróciły uwagę na potencjalną możliwość ich łącznego wykorzystania jako zespołu. Takie rozwiązanie, w którym wykorzystywane są wskazania pewnej liczby indywidualnych klasyfikatorów, zapewnia uzyskanie wyniku klasyfikacji nie gorszego od najlepszego elementu zespołu. Głównym założeniem przy tworzeniu zespołu jest komplementarność modeli, polegająca na poprawie skuteczności w niektórych obszarach przestrzeni cech. Ważną kwestią jest zasada wskazywania klasyfikacji przez zespół. Jedną z możliwości jest powierzenie tego zadania wyspecjalizowanemu klasyfikatorowi, którego zmiennymi wejściowymi są wskazania składowych zespołu, zaś wynikiem działania: decyzja o klasyfikacji. Tabela 5 zawiera wyniki działania zespołów różniących się algorytmem decyzyjnym (zgodnie ze stosowaną w pracy konwencją). Wejściami modelu klasyfikacyjnego są wektory wskazań algorytmów składowych zespołu (łącznie 99 wartości binarnych, odpowiednio do wyjść algorytmów pierwszego poziomu przetwarzania).

Łatwo dostrzec, że wykorzystanie wskazań dziewięciu względnie słabych klasyfikatorów, z zastosowaniem adaptacyjnego algorytmu decyzyjnego poprawia jakość klasyfikacji. Spośród przebadanych modeli najlepszy wynik dają różne odmiany drzew decyzyjnych: Gradient Boosting Machines oraz Distributetd Random Forest. W dalszym ciagu największe problemy związane są $\mathrm{z}$ wyodrębnianiem kompleksów 8, 9 i $3 z$.

Rysunek 1 przedstawia przestrzenny rozkład rozmieszczenia punktów (pikseli) należących do zbioru walidacyjnego z zaznaczeniem: $1 \mathrm{~A}$ - pikseli poprawnie identyfikowanych przez zespół klasyfikatorów $\mathrm{z}$ algorytmem decyzyjnym GBM, 1B - pikseli błędnie identyfikowanych przez zespół, 1C - pikseli należących do kompleksów 8 i 9, błędnie identyfikowanych przez zespół, 1D - pikseli należących do kompleksu $3 z$ błędnie identyfikowanych. Należy zauważyć, że punkty identyfikowane wadliwie są rozmieszczone stosunkowo równomiernie, co oznacza, że algorytm nie wykazuje preferencji wobec konkretnych obszarów. Błędy wskazań, jak można przypuszczać, są powodowane po części przez niedokładności digitalizacji.

Dzięki zastosowaniu przez algorytmy udostępniane na stronie Oxdata.com, funkcji softmax jako wyjścia modeli, każde wskazanie indywidualne stanowi oszacowanie rozkładu prawdopodobieństwa przynależności konkretnego piksela do konkretnego kompleksu. Uśrednienie wartości składowych wektorów tworzy 11-elementowy wektor rozkładu prawdopodobieństwa dla przeciętnego wektora reprezentującego określony kompleks. Pozwala to pośrednio na poznanie podobieństwa średnich wektorów prawdopodobieństwa odpowiednich kompleksów.

Rysunek 2 przedstawia sporządzony przy zastosowaniu algorytmu skalowania wielowymiarowego (MDS-MultiDimensional Scaling) wykres rozmieszczenia średnich wskazań wektorów prawdopodobieństwa dla kompleksów. Interpretacja wykresu, oparte-

TABELA 5. Procentowa poprawność wskazań elementów zbioru walidacyjnego przez zespół klasyfikatorów z różnymi algorytmami decyzyjnymi (algorytm stacking classification). SAE (99-50-25-11), FSM (300), DL (99-200-200-11), GBM (200, 50, 10), DL750 (99-750-200-11), GBMBig (250, 50, 10), DFRBig (250, 50, 10), GBMveryBig(400, 50, 10)

TABLE 5. The percentage accuracy of the elements identification of the set validation by a ensamble of classifiers with different decision-making algorithms (algorithm stacking classification). SAE (99-50-25-11), FSM (300), DL (99-200-200-11), GBM (200, $50,10)$, DL750 (99-750-200-11) GBMBig $(250,50,10)$ DFRBig $(250,50,10)$ GBMveryBig $(400,50,10)$

\begin{tabular}{|c|c|c|c|c|c|c|c|c|c|}
\hline KOMP & SAE & FSM & SSV & $\mathrm{DL}$ & GBM & DL750 & GBMBig & DRFBig & GBMveryBig \\
\hline $\mathrm{K} \_2$ & 95,3 & 93 & 94,9 & 97,9 & 95,4 & 97,4 & 96 & 96,4 & 96,6 \\
\hline $\mathrm{K}^{-} 3$ & 91,5 & 90,7 & 91,4 & 47,7 & 93,1 & 74,9 & 94,6 & 95,2 & 95,4 \\
\hline $\mathrm{K}^{-} 4$ & 90,8 & 89,4 & 88,8 & 68,4 & 91,8 & 87,1 & 93,4 & 94,2 & 94,5 \\
\hline $\mathrm{K}^{-} 5$ & 91,8 & 91,5 & 92 & 76,1 & 93,4 & 91,5 & 94,5 & 95 & 95,2 \\
\hline $\mathrm{K}^{-} 6$ & 93,6 & 92,2 & 91,4 & 95,5 & 94,4 & 93,9 & 95,3 & 95,5 & 95,9 \\
\hline $\mathrm{K}^{-} 7$ & 91,3 & 93,4 & 91,6 & 91,3 & 94,7 & 95,1 & 95,4 & 95,7 & 95,7 \\
\hline $\mathrm{K}_{-}^{-} 8$ & 73,8 & 74,2 & 73,1 & 69,2 & 77,1 & 70,7 & 79 & 79,6 & 80 \\
\hline $\mathrm{K}^{-} 9$ & 79,9 & 74 & 78,9 & 78,9 & 82,3 & 80,2 & 83,4 & 84,5 & 84,3 \\
\hline $\mathrm{Z}_{-1}^{-1}$ & 97,6 & 100 & 0 & 0 & 100 & 97,6 & 100 & 97,6 & 100 \\
\hline$Z^{-} 2$ & 97,2 & 94,6 & 97,7 & 97,4 & 97,2 & 91,1 & 97,3 & 97,6 & 97,4 \\
\hline Z_3 & 82 & 84,7 & 79,1 & 77,1 & 82,7 & 87,2 & 82,9 & 82,1 & 83,1 \\
\hline Razem & 91.4 & 90,2 & 90.6 & 84,2 & 92,5 & 89,5 & 93,3 & 93,7 & 93,9 \\
\hline
\end{tabular}



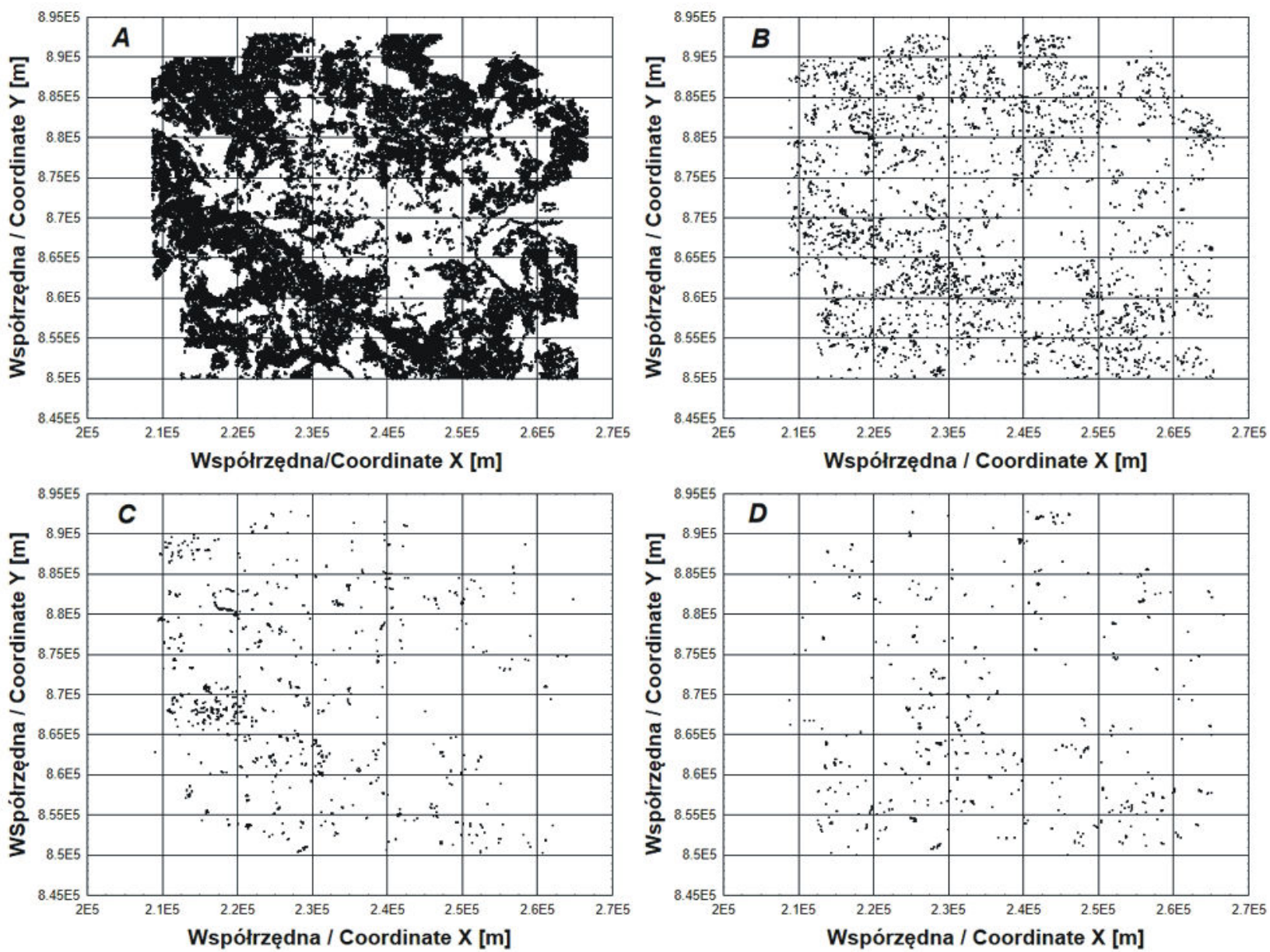

RYSUNEK 1. Położenie punktów zbioru walidacyjnego: A - poprawnie zaklasyfikowane przez zespół klasyfikatorów z algorytmem decyzyjnym GBM, B - błędnie zaklasyfikowane, C - błędnie zaklasyfikowane, należące do kompleksów 8 i 9, D - błędnie zaklasyfikowane należące do kompleksu $3 \mathrm{z}$

FIGURE 1. Location points of the validation set: A - correctly classified by an ensemble of classifiers with decision-making algorithm GBM; B - incorrectly classified; C - incorrectly classified belonging to the soil complexes 8 and 9, D - incorrectly classified belonging to the soil complex $3 \mathrm{z}$

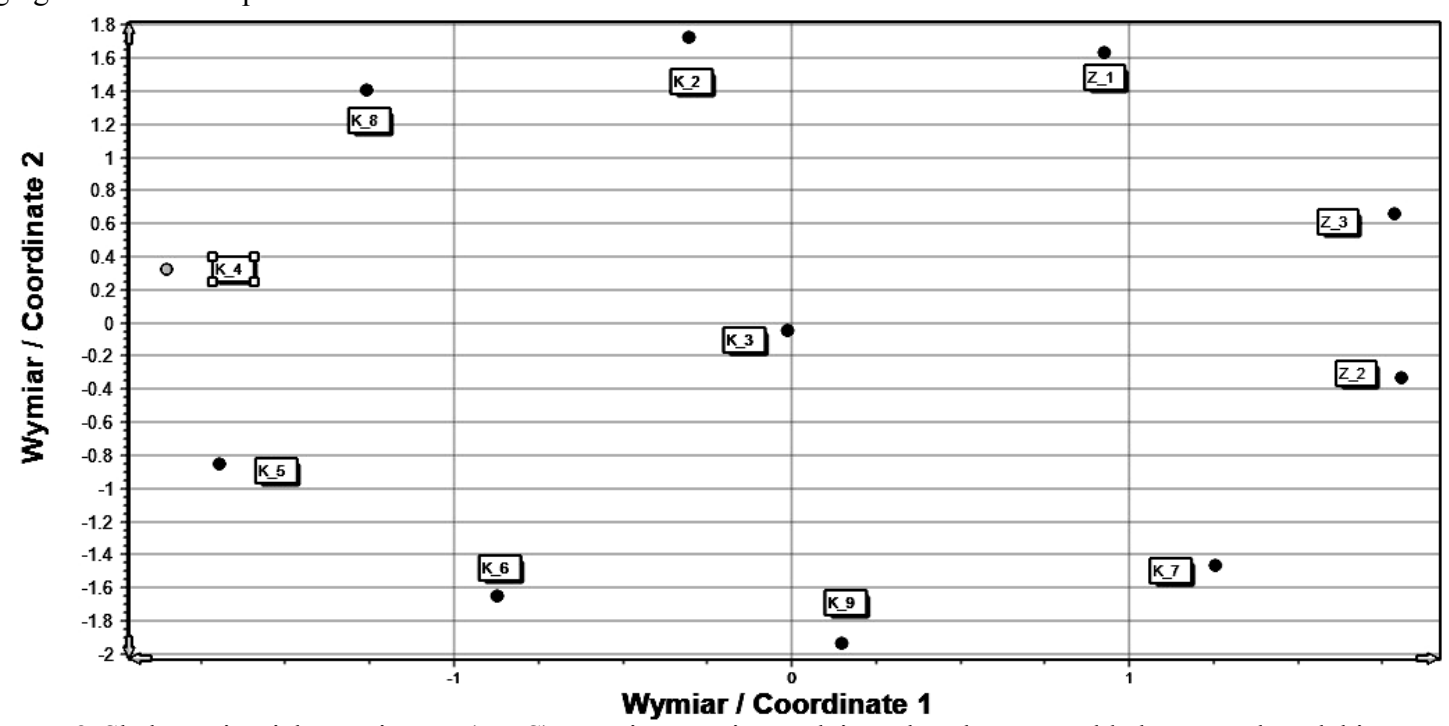

RYSUNEK 2. Skalowanie wielowymiarowe (MDS): rozmieszczenie uśrednionych wektorów rozkładów prawdopodobieństwa wskazań kompleksów. Symbole: K_2, K_3, K_4, K_5, K_6, K_7, K_8, K_9 odnoszą się do wektorów prawdopodobieństw kompleksów gruntów ornych, Z $1, \mathrm{Z} 2$ i Z 3 odnosza sie do kompleksów trwałych użytków zielonych

FIGURE 2. Multidimensional scaling (MDS): distribution of averaged vectors of probability distributions of complex indications. Symbols: K 2, K 3, K 4, K 5, K 6, K _ 7, K 8, K 9 refer to the vectors of probabilities complexes of arable land; Z 1, Z 2 and Z 3 refer to the complex of permanent grassland 
go na transformacji 11-wymiarowej przestrzeni cech do przestrzeni 2-wymiarowej, polega na oszacowaniu odległości między punktami: bliższe są podobne do siebie, odleglejsze różnią się w większym stopniu. Wykres na rysunku 2 informuje, że przeciętnie, zespół klasyfikatorów poprawnie rozdziela kompleksy. Inaczej jednak wygląda ten problem jeżeli weźmie się pod uwagę pojedyncze wskazania zespołu.

Rysunek 3 jest wykresem rozmieszczenia losowo wybranych ( $8 \%$ zbioru walidacyjnego z zachowaniem proporcji klas) elementów zbioru walidacyjnego zgodnie z algorytmem MDS, na podstawie zróżnicowania wektorów prawdopodobieństwa oszacowanych przez zespół klasyfikatorów. W wylosowanym zbiorze znajdują się elementy sklasyfikowane poprawnie i błędnie przez zespół. Nakładanie się lub bliskie sąsiedztwo punktów należących do różnych kompleksów sygnalizuje problemy z ich rozróżnieniem.

Jak wynika z opisanych prób, pomimo użycia pracochłonnych i czasochłonnych metod ekstrakcji reguł klasyfikacyjnych, uzyskany stopień poprawności identyfikacji kompleksów nie przekracza 95\%, zaś w odniesieniu do niektórych kompleksów, jest niższy, spadając do $80 \%$.

W dokumentowaniu gleb można poszukiwać innych modeli: rozmieszczenia typów gleb, klas bonitacyjnych, typów gospodarki wodnej itp. Nie wiadomo jakiego stopnia dokładności rozróżnienia tych jednostek należy oczekiwać. W zaprezentowanym ujęciu każdy piksel jest związany z wektorem rozkładu prawdopodobieństwa jego przynależności do określonej klasy. W jego interpretacji przyjmuje się, że wskazaną jednostką (klasą, kompleksem, typem gleby) jest ta, którą wyróżnia najwyższa wartość prawdopodobieństwa.

Należy zauważyć, że związany z konkretnym miejscem przestrzeni wektor prawdopodobieństwa jednostek (na przykład kompleksów) jest sam w sobie istotną informacją, potwierdzająca rozmyty charakter rozgraniczenia jednostek glebowych, sztucznie dyskretyzowany w dokumentacji analogowej. Teoretycznie możliwe jest uszczegółowienie tych rozgraniczeń przez odpowiednie obserwacji terenowe.

Rysunek 4 przedstawia histogram maksymalnych wartości wskazań w wektorach zbioru walidacyjnego poprawnie sklasyfikowanych (dopasowanie rozkładu beta). Histogram wskazuje, że w zbiorze przypadków poprawnie sklasyfikowanych dominują wysokie wartości prawdopodobieństwa. Sporadycznie są przypadki niższych wskazań, przekraczających 0,5.

Rysunek 5 przedstawia taki sam histogram dla przypadków zbioru walidacyjnego sklasyfikowanych błędnie przez algorytm. Tu również zaznacza się asymetria rozkładu maksimów. Antropomorfizując moż- na zauważyć, że zastosowany zespół algorytmów wskazuje błędnie niektóre przypadki z dużym przekonaniem. Przy niezmienionym zestawie zmiennych wejściowych zdecydowana poprawa wskazań nie jest możliwa. Ubóstwo dostarczanych informacji uniemożliwia w pełni wiarygodną diagnozę siedliskową, jakkolwiek przeważają wskazania poprawne. $\mathrm{W}$ takich okolicznościach algorytm klasyfikacyjny powinien być stosowany ze świadomością tylko częściowej wiarygodności. W grę wchodzi także postępowanie zmierzające do poprawy wskazań przez włączenie do diagnozy siedliskowej, w watpliwych przypadkach, badań terenowych. Zakładając, że algorytm decyzyjny akceptuje prawdopodobieństwa wskazań powyżej pMAX $=0,8$; w takim zbiorze znalazłoby się (spośród 67365 elementów zbioru walidacyjnego) 59187 przypadków poprawnie sklasyfikowanych oraz 2053 elementów sklasyfikowanych niepoprawnie, bez możliwości weryfikacji z uwagi na wysokie prawdopodobieństwo wskazania. Pozostałe przypadki $(4282+2043=6325)$ należałoby potraktować jako wymagające sprawdzenia terenowego.

Zakładając, że wynik weryfikacji terenowej jest zawsze poprawny, oznaczałoby to uzyskanie poprawności identyfikacji wynoszącej około 97\%. Można przypuszczać, że rzeczywista poprawność klasyfikacji (kompleksów, typów gleb, klas bonitacyjnych), zwłaszcza w ujęciu aktualnej dokumentacji analogowej nie jest konkurencyjna dla tej wielkości.

\section{PODSUMOWANIE}

Mapa glebowo-rolnicza, nawet uzupełniona o dane morfologiczne oraz ich pochodne (konfiguracja, spadek, odległość od cieków itp.) stanowi stosunkowo ubogie źródło informacji dających możliwość wyodrębnienia reguł wnioskowania o siedliskach oraz innych klasyfikacjach gleb na podstawie cech. Dane te są zgeneralizowane, zaś digitalizacja konturów glebowych jak i morfologii terenu są obciążone błędami. Można jednak przypuszczać, że w ciągu kolejnych lat odczuwana będzie potrzeba ułatwienia dostępu do informacji środowiskowych, w tym do uwarunkowań kształtowania się gleb i siedlisk. Wydaje się, że ograniczenie się do ujmowania zróżnicowania przestrzennego gleb wyłącznie w ujęciu dyskretnym będzie niewystarczające. Gleby są z natury zmienne przestrzennie, a podlegając różnorodnym wpływom zewnętrznym zmieniają się także z czasem, szczególnie w obszarach oddziaływania przemysłu. W krajach anglosaskiego obszaru językowego, jak też w krajach Unii Europejskiej, wykorzystywane są w mniejszym lub większym stopniu odmienne, bazujące na regułach logicznych metody opisu właściwo- 


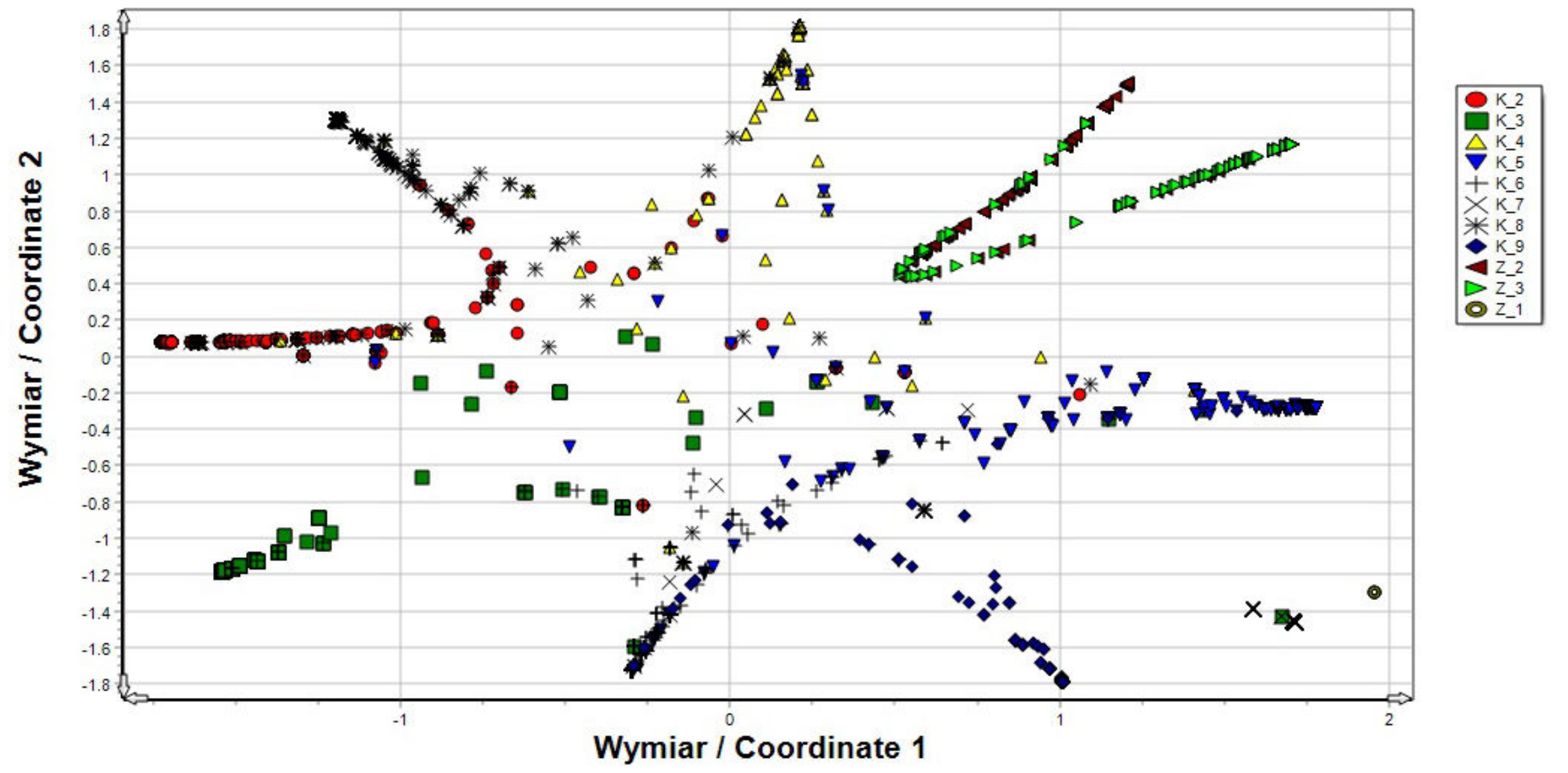

RYSUNEK 3. Skalowanie wielowymiarowe: wykres rozmieszczenia pikseli należących do różnych kompleksów na podstawie wektorów rozkładów prawdopodobieństw przynależności do określonych kompleksów. Symbole: $\mathrm{K} \_2, \mathrm{~K} \_3, \mathrm{~K} \_4, \mathrm{~K} \_5, \mathrm{~K} \_6, \mathrm{~K} \_7, \mathrm{~K} \_8, \mathrm{~K} \_9$ odnoszą się do wektorów prawdopodobieństw kompleksów gruntów ornych, Z_1, Z_2 i Z_3 odnoszą się do kompleksów trwałych użytków zielonych

FIGURE 3. Multidimensional scaling: vector probability distribution indicated by the decision-making module GBM. Symbols: K_2, K_3, K_4 , K_5, K_6, K_7, K_8, K_9 refer to the vectors of probabilities complexes of arable land; $Z_{-} 1, Z_{2} 2$, and $Z_{-} 3$ refer to the complex of permanent grassland 


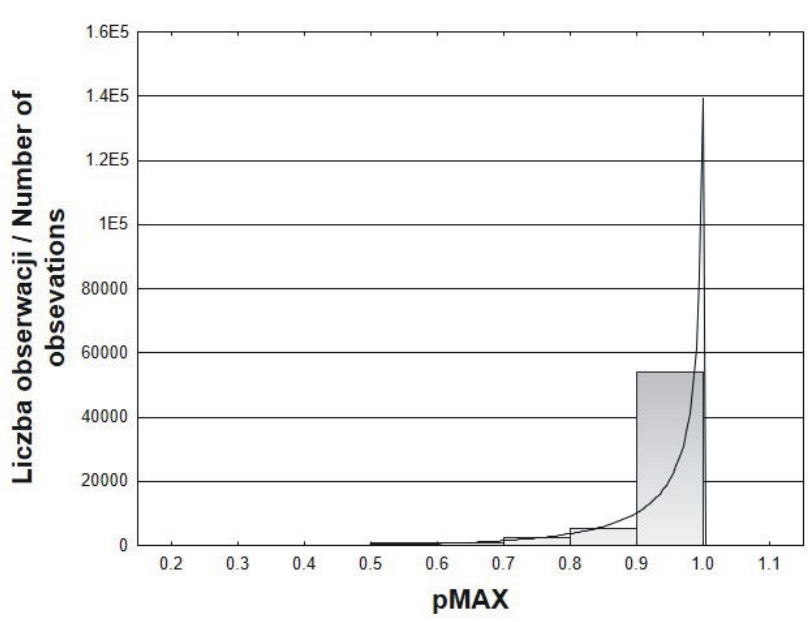

RYSUNEK 4. Histogram maksymalnej wartości wektora wskazań kompleksów przez zespół klasyfikatorów z modułem decyzyjnym GBM: część zbioru walidacyjnego sklasyfikowana poprawnie FIGURE 4. Histogram of the maximum value of the display vector complexes by an ensemble of classifiers of GBM decision-making module: part of a set of validation classified correctly

ści gleb. W każdym przypadku podstawowym źródłem danych jest analogowa dokumentacja kartograficzna gleb, której digitalizacja tworzy podstawę prowadzącą do uszczegółowiania informacji na podstawie obserwacji terenowych. $Z$ czasem doprowadzi to do utworzenia precyzyjnego systemu oceny gleb, o wysokiej rozdzielczości. Punktem startu do budowy sytemu bazującego na danych, jest $\mathrm{w}$ tym przypadku model, który może powstać $\mathrm{w}$ drodze zastosowania algorytmów adaptacyjnych (Zhu et al. 2001, McBratney 2003). Jest znaczna liczba algorytmów przydatnych do tego celu. Niektóre $\mathrm{z}$ nich przetestowano $\mathrm{w}$ ramach tej pracy. Wydaje się, że żaden z pojedynczych modeli adaptacyjnych nie może być traktowany jako dostatecznie mocny i wiarygodny. W bardzo złożonych warunkach fizjograficznych odpowiednim podejściem może być zespół klasyfikatorów, wyselekcjonowany spośród testowanych modeli. W każdym przypadku zwiększenie zakresu informacji wejściowych modeli (na przykład o dane dotyczące położenia wody gruntowej) podwyższa ich skuteczność. Zamiar opracowania powszechnego modelu cyfrowego gleb opartego na regułach, o wysokiej rozdzielczości powinien być rozpatrywany raczej w ujęciu regionalnym lub nawet lokalnym.

\section{PODZIĘKOWANIA}

Badania finansowane ze środków przyznanych przez MNiSW na utrzymanie potencjału badawczego Wydziału Geodezji Górniczej i Inżynierii Środowiska Akademii Górniczo-Hutniczej im. S. Staszica w Krakowie, projekt nr 11.11.150.008.

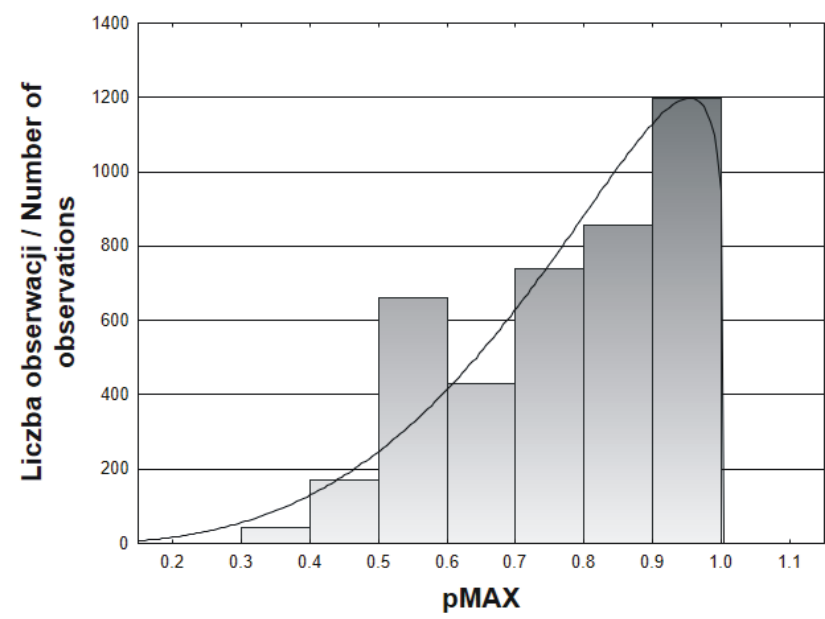

RYSUNEK 5. Histogram maksymalnej wartości wektora wskazań kompleksów przez zespół klasyfikatorów z modułem decyzyjnym GBM: część zbioru walidacyjnego sklasyfikowana niepoprawnie FIGURE 5. Histogram of the maximum value of the display vector complexes by an ensemble of classifiers of GBM decision-making module: part of the validation set classified incorrectly

\section{LITERATURA}

Białousz S., Chmiel J., Fijałkowska A., Różycki S., 2010. Wykorzystanie zdjęć satelitarnych i technologii GIS w aktualizacji jednostek glebowo-krajobrazowych - przykłady dla opracowań małoskalowych. Archiwum Fotogrametrii, Kartografii i Teledetekcji 21: 21-32.

Bielska A., Jaroszewicz J., 2012. Przegląd metod wykorzystujących funkcje rozmyte i analizy wielokryterialne do opracowania cyfrowych map glebowo-rolniczych. Acta Scientiarum Polonorum. Geodesia et Descriptio Terrarum 11(2): 5-15.

Cortes C., Vapnik V., 1995. Support-vector networks. Machine Learning 20, pp. 273-279.

Duch W., Diercksen G.H.F., 1995. Feature Space Mapping as a universal adaptive system. Computer Physics Communications vol. 81, pp. 341-371.

Friedman J., 2000. Greedy Function Approximation: A Gradient Boosting Machine. Annals of Statistics 29: 1189-1232.

Jankowski N., 2003. Ontogeniczne sieci neuronowe. O sieciach zmieniających swoją strukturę. Exit.

Jones A., Montanarella L., Jones R. (ed.), 2005. Soil Atlas of Europe. JRC EC, European Soil Bureau Network, 128 pp. Office for Official Publications of the European Communities.

Kleinberg E., 1996. An Overtraining-Resistant Stochastic Modeling Method for Pattern Recognition). Annals of Statistics 24(6): 2319-2349.

Kurzyński M., 1997. Rozpoznawanie obiektów. Metody statystyczne, Politechnika Wrocławska.

LeCunY., BengioY., Hinton G.E., 2015. Deep Learning. Nature vol. 521, pp. 436-444.

McBratney A.B., Mendonça Santos M.L., Minasny B., 2003. On digital soil mapping. Geoderma 117 (1-2): 3-52.

Palm R.B., 2012. Prediction as a candidate for learning deep hierarchical models of data. Master thesis IMM2012-06284.

Strzemski M., Bartoszewski Z., Czarnowski F., Dombek E., Siuta J., Truszkowska R., Witek T., 1964. Instrukcja w sprawie wykonywania map glebowo-rolniczych w skali 1: 5000 
i 1: 25000 oraz map glebowo-przyrodniczych w skali 1:25 000, Załącznik do Zarządzenia nr 115 Ministra Rolnictwa z dnia 28 lipca 1964 r. w sprawie organizacji prac gleboznawczoi rolniczo-kartograficznych (Dz.Urz. Min. Rol. Nr 19, poz. 121), Warszawa.

Strzemski M., Siuta J., Witek T., 1973. Przydatność rolnicza gleb Polski. PWRiL Warszawa, ss. 285.

Tadeusiewicz R., 1993. Sieci neuronowe. Warszawa: Akademicka Oficyna Wydawnicza RM.
Zhou G., Hull R., King R., Franchitti JC., 2006. Supporting data integration and warehousing using H2O. IEEE Data Engineering, vol. 18, pp. 29-48.

Zhu A.X., Hudson B., Burt J., Lubich K., Simonsen D., 2001. Soil mapping using GIS, expert knowledge, and fuzzy logic. Soil Science Society of America Journal 65: 1463-1472.

Received: November 16, 2015

Accepted: February 4, 2016

\title{
Modeling the position of agricultural suitability units of soils on the basis of the limited physiographic information processing with digitized cartographic materials
}

\begin{abstract}
The aim of the study was to test the ability to model soil capability units diversity of on the basis of limited information about particle size and morphology of the terrain data. The data obtained from digitization of maps of agricultural soil and topography of the region of the Upper Silesian Industrial District. Rule extraction tools and build models were algorithms in the field of computational intelligence: different versions of decision trees, neural networks and deep learning algorithms. The best algorithms allow for correct classification to $90 \%$ of the elements of the validation set. The design ensemble of specialized classifier algorithm increased the efficiency of decision-making algorithm to identify a set of validation to about $94 \%$. Proper selection decision algorithm allows the estimation of the likelihood vector belonging to a complex object. Computational intelligence algorithms can be considered as a tool for extracting classification rules from the collection of data on soils on the local or regional level.
\end{abstract}

Keywords: Agricultural soil map, soil capability units, digitization of maps, computational intelligence, adaptive models 